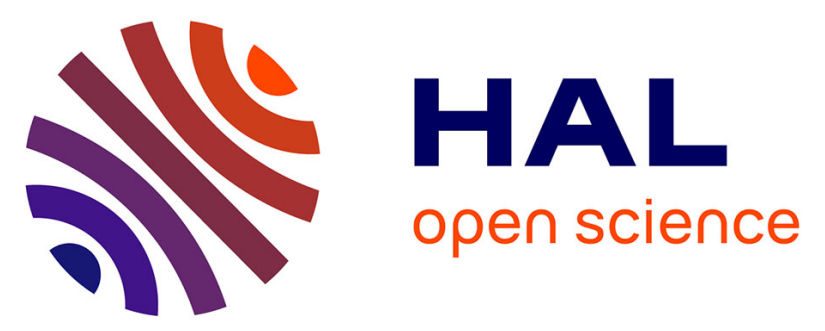

\title{
Textures, water content and degassing of silicic andesites from recent plinian and dome-forming eruptions at Mount Pelée volcano (Martinique, Lesser Antilles arc)
}

Caroline Martel, Jean-Louis Bourdier, Michel Pichavant, Hervé Traineau

\section{- To cite this version:}

Caroline Martel, Jean-Louis Bourdier, Michel Pichavant, Hervé Traineau. Textures, water content and degassing of silicic andesites from recent plinian and dome-forming eruptions at Mount Pelée volcano (Martinique, Lesser Antilles arc). Journal of Volcanology and Geothermal Research, 2000, 96, pp.191-206. 10.1016/S0377-0273(99)00147-X . hal-00115128

\section{HAL Id: hal-00115128 \\ https://hal-insu.archives-ouvertes.fr/hal-00115128}

Submitted on 7 May 2013

HAL is a multi-disciplinary open access archive for the deposit and dissemination of scientific research documents, whether they are published or not. The documents may come from teaching and research institutions in France or abroad, or from public or private research centers.
L'archive ouverte pluridisciplinaire HAL, est destinée au dépôt et à la diffusion de documents scientifiques de niveau recherche, publiés ou non, émanant des établissements d'enseignement et de recherche français ou étrangers, des laboratoires publics ou privés. 


\title{
Textures, water content and degassing of silicic andesites from recent plinian and dome-forming eruptions at Mount Pelée volcano (Martinique, Lesser Antilles arc)
}

\author{
C Martel $^{\mathrm{a}}$ J.-L Bourdier ${ }^{\mathrm{b}}$ M Pichavant ${ }^{\mathrm{a}} \mathrm{H}$ Traineau $^{\mathrm{c}}$
}

- $\quad{ }^{\text {a }}$ CRSCM-CNRS and FR 009, 1A rue de la Férollerie, 45071 Orléans cedex 2, France

- $\quad{ }^{\mathrm{b}}$ UMR-CNRS 6530 and FR 009, Université d'Orléans, BP 6759, 45067 Orléans cedex 2, France

- $\quad{ }^{\mathrm{c}}$ CRV Clermont-Ferrand, BRGM, BP 6009, Orléans cedex 2, France

\begin{abstract}
Previous petrological and phase-equilibrium experimental studies on recent silicic andesites from Mount Pelée volcano have evidenced comparable pre-eruptive conditions for plinian and dome-forming (pelean herein) eruptions, implying that differences in eruptive style must be primarily controlled by differences in degassing behaviour of the Mount Pelée magmas during eruption. To further investigate the degassing conditions of plinian and pelean magmas of Mount Pelée, we study here the most recent Mount Pelée's products (P1 at 650 years B.P., 1902, and 1929 eruptions, which cover a range of plinian and pelean lithologies) for bulk-rock vesicularities, glass water contents (glass inclusions in phenocrysts and matrix glasses) and microtextures. Water contents of glass inclusions are scattered in the plinian pumices but on average compare with the experimentally-deduced pre-eruptive melt water content (i.e., 5.3$6.3 \mathrm{wt} . \%$ ), whereas they are much lower in the dominant pelean lithologies (crystalline, poorly vesicular lithics and dome samples). This indicates that the glass inclusions of the pelean products have undergone strong leakage and do not represent pre-eruptive water contents. The water content of the pyroclast matrix glasses are thought to closely represent the residual water content in the melt at the time of fragmentation. Determination of the water contents of both the pre-eruptive melt and matrix glasses allows the estimation of the amount of water exsolved upon syn-eruptive degassing. We find the amount of water exsolved during the eruptive process to be higher in the pelean products than in the plinian ones, typically 90 100 and $65-70 \%$ of the initial water content, respectively. The vesicularities calculated from the amount of exsolved water compare with the measured vesicularities for the plinian pumices, consistent with a closed-system, near-equilibrium degassing up to fragmentation. By contrast, the low residual water contents, low groundmass vesicularities and extensive groundmass crystallization of the pelean products are direct evidence of open-system degassing. Microtextural features, including silica-bearing and silica-free voids in the pelean lithologies may represent a two-stage vesiculation.
\end{abstract}

\section{Keywords}

- silicic andesites;

- Plinian;

- Pelean 


\section{Introduction}

Alternation of eruptive styles, i.e., dome-forming (pelean) and plinian eruptions, is common at silicic (e.g., rhyolitic and andesitic) volcanoes. Stratigraphic studies of Mount Pelée, an active andesitic stratovolcano of the Lesser Antilles arc, have revealed at least seven plinian eruptions for the last 10,000 years and a still larger number of dome-forming eruptions recorded by block-and-ash flow (BAF hereafter) and high-velocity pyroclastic flow (HVPF hereafter) deposits Roobol and Smith, 1976, Westercamp and Traineau, 1983a, Westercamp and Traineau, 1983b, Traineau et al., 1989 and Smith and Roobol, 1990. The transition from a pelean regime to a plinian one is stratigraphically suggested in the P1 eruption, 650 years B.P. Boudon et al., 1994 and Villemant et al., 1996.

Early models for the transition between the pelean and plinian regimes considered the common sequence of an explosive phase followed by lava dome extrusion. This sequence was ascribed to pre-eruptive volatile gradients, the tapped magma being progressively less and less rich in volatiles (e.g., Eichelberger and Westrich, 1981 and Fink, 1983). Although widely accepted and applied to many volcanoes, including Mount Pelée (Smith and Roobol, 1990), this model has been challenged and alternative mechanisms based on gas loss through permeable conduit wall have been proposed Eichelberger et al., 1986, Jaupart and Allègre, 1991 and Fink et al., 1992. Geological evidence supporting this alternative model includes: (1) eruptions of small enough magma-volumes that significant volatile stratification in the magma chamber is precluded; (2) comparable volatile contents found in glass inclusions in phenocrysts from both the plinian and dome phases of a single eruption; (3) comparable phenocryst assemblages and phenocryst compositions in the pelean and plinian products.

The pre-eruptive conditions at Mount Pelée were experimentally investigated by Martel et al. (1998) and were found to be identical for plinian and pelean samples, i.e., $P=2 \pm 0.5 \mathrm{~kb}$ (depth 6-9 km), $T=875-900^{\circ} \mathrm{C}, f \mathrm{O}_{2}=\mathrm{NNO}+0.4-0.8, \mathrm{H}_{2} \mathrm{O}$ melt content $=5.3-6.3 \mathrm{wt} . \%$ (slightly under saturated, saturation being found to be $\sim 6.9 \mathrm{wt} . \% \mathrm{H}_{2} \mathrm{O}$ ). Therefore, the differences in eruptive style in the recent activity of Mount Pelée cannot be ascribed to systematic differences in preeruptive water content, but may be acquired upon degassing during magma ascent and eruption Martel et al., 1998 and Villemant and Boudon, 1998.

The present study is aimed at (1) documenting the vesicularities, groundmass microtextures, and glass water contents (both matrix glasses and glass inclusions in phenocrysts) in a wide range of lithologies, specifically from the P1 plinian and the P1, 1902-04 and 1929-32 HVPF and BAF products, and (2) using the obtained data as constraints on the degassing processes and on the differences in degassing between the two observed eruptive regimes.

\section{Studied material}

\subsection{Plinian material}

The P1 eruption in the stratigraphic nomenclature of Westercamp and Traineau, 1983a and Westercamp and Traineau, 1983b is the last plinian event recorded at Mount Pelée. The plinian P1 deposits (Fig. 1) comprise a pumice fallout layer topped by a valley-fill pumice flow of up to $60 \mathrm{~m}$ thick. The $\mathrm{P} 1$ plinian products dominantly consist of juvenile pumices, oxidized xenoliths, and macroscopically fresh, grey dense lithics. From field inspection, it is unclear whether the grey dense lithics are accessory (i.e., xenoliths) or juvenile lithics representing quenched or degassed P1 magma. In this study, we examine 
pumice clasts from the P1 fallout layer and from the upper pumice flow deposits of the Rivière du Prêcheur valley (Table 1)

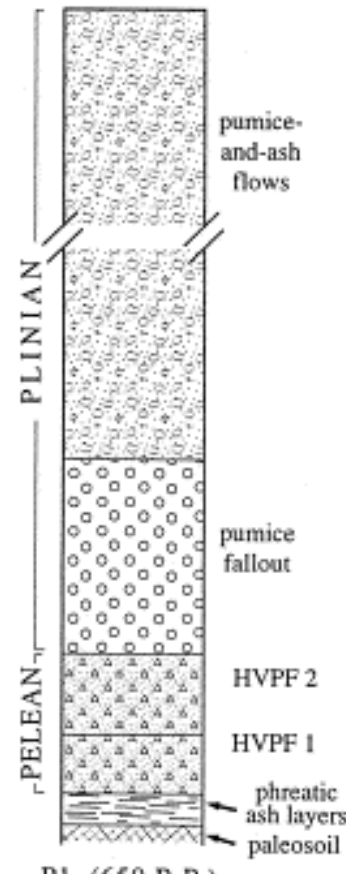

P1 (650 B.P.)

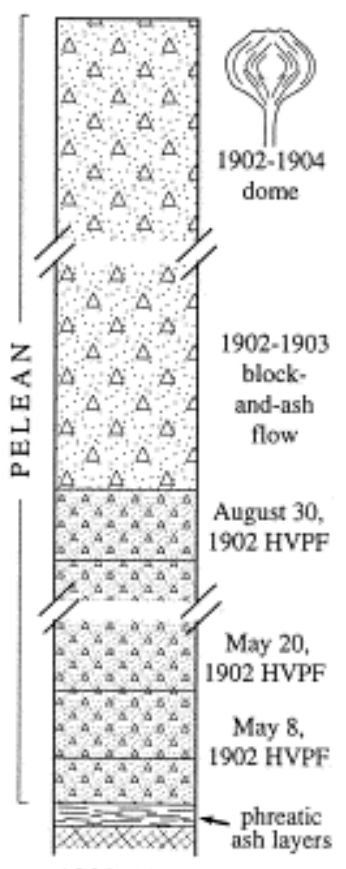

1902-1904

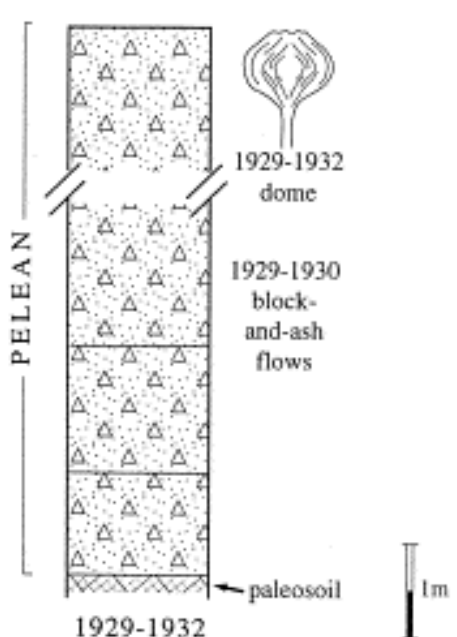

1929-1932

Fig. 1. Schematic eruptive sequences of the P1 (after Boudon et al., 1994 and Villemant et al., 1996), 1902-1904 and 1929-1932 (after Bourdier et al., 1989) eruptions. HVPF (high-velocity pyroclastic flow) and block-and-ash flow units are lithic-dominated whereas the plinian deposits are mostly pumices. 
Table 1. Description of samples used in this studyBAF for block-and-ash flow; HVPF for high-velocity pyroclastic flow.

\begin{tabular}{|c|c|c|c|}
\hline $\begin{array}{l}\text { Eruption } \\
\text { unit }\end{array}$ & $\begin{array}{l}\text { Eruption } \\
\text { type }\end{array}$ & Lithology & Sample number \\
\hline $\mathrm{P} 1$ & $\begin{array}{l}\text { Plinian- } \\
\text { fallout }\end{array}$ & pumices & 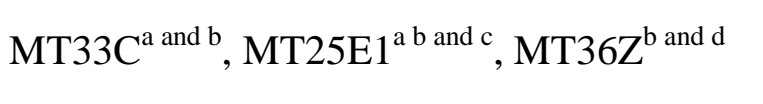 \\
\hline P1 & $\begin{array}{l}\text { Plinian- } \\
\text { pumice flow }\end{array}$ & pumices & MT38Wa, b and d \\
\hline 1929 & Pelean-dome & $\begin{array}{l}\text { crystalline } \\
\text { lithics }\end{array}$ & $\mathrm{MT}_{4} \mathrm{P}^{\mathrm{a}, \mathrm{b} \text { and c }}, \mathrm{MT} 4 \mathrm{R}^{\mathrm{a}}, \mathrm{MI}^{\mathrm{b}}$ \\
\hline 1902 & Pelean-dome & $\begin{array}{l}\text { crystalline } \\
\text { lithics }\end{array}$ & $\mathrm{M} 2^{\mathrm{b}}$ \\
\hline 1929 & Pelean-BAF & $\begin{array}{l}\text { crystalline } \\
\text { lithics }\end{array}$ & 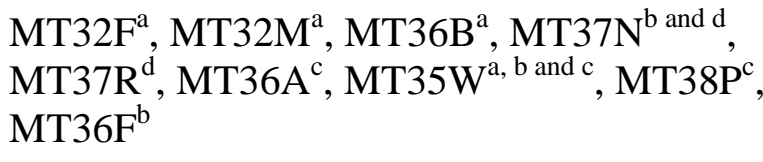 \\
\hline $\begin{array}{l}\text { 1902, May } \\
8\end{array}$ & $\begin{array}{l}\text { Pelean- } \\
\text { HVPF }\end{array}$ & $\begin{array}{l}\text { crystalline } \\
\text { lithics }\end{array}$ & MT32Aa and b, MT37B ${ }^{d}$ \\
\hline $\begin{array}{l}\text { 1902, } \\
\text { August } 30\end{array}$ & $\begin{array}{l}\text { Pelean- } \\
\text { HVPF }\end{array}$ & $\begin{array}{l}\text { crystalline } \\
\text { lithics }\end{array}$ & MT36V \\
\hline $\mathrm{P} 1$ & $\begin{array}{l}\text { Pelean- } \\
\text { HVPF }\end{array}$ & $\begin{array}{l}\text { crystalline } \\
\text { lithics }\end{array}$ & MT36 $\mathrm{P}^{\mathrm{b}}$ \\
\hline $\begin{array}{l}\text { 1902, } \\
\text { August } 30\end{array}$ & $\begin{array}{l}\text { Pelean- } \\
\text { HVPF }\end{array}$ & $\begin{array}{l}\text { vitreous } \\
\text { lithics }\end{array}$ & MT36V ${ }^{b}$ \\
\hline P1 & $\begin{array}{l}\text { Pelean- } \\
\text { HVPF }\end{array}$ & $\begin{array}{l}\text { vitreous } \\
\text { lithics }\end{array}$ & MT33Sa and b, MT35N ${ }^{a}$, MT36Pa, b and d \\
\hline $\begin{array}{l}\text { 1902, } \\
\text { August } 30\end{array}$ & $\begin{array}{l}\text { Pelean- } \\
\text { HVPF }\end{array}$ & $\begin{array}{l}\text { dense } \\
\text { pumices }\end{array}$ & $\mathrm{MT}^{2} 6 \mathrm{~V}^{\mathrm{b}}$ \\
\hline $\mathrm{P} 1$ & $\begin{array}{l}\text { Pelean- } \\
\text { HVPF }\end{array}$ & $\begin{array}{l}\text { dense } \\
\text { pumices }\end{array}$ & $\begin{array}{l}\text { MT33Ta b and c, MT33W } \mathrm{W}^{\mathrm{a}}, \mathrm{MT} 35 \mathrm{~N}^{\mathrm{a}} \text {, } \\
\text { MT36Pa, b and d }\end{array}$ \\
\hline
\end{tabular}

Analyses of glass compositions and glass water contents.

b

Textural SEM observations

$\mathrm{c}$

Microlite analyses.

d

Vesicularity measurements (sets of around 100 lapilli). 


\subsection{Pelean material}

Pelean material from dome-forming eruptions comprises rocks from the well-documented 1902-1904 (Lacroix, 1904) and 1929-1932 (Perret, 1935) eruptions (hereafter called for brevity the 1902 and 1929 eruptions, respectively). Both eruptions included the extrusion of a lava dome and dome-generated low-energy BAFs channelled in the Rivière Blanche valley. In addition, unchannelled HVPFs occurred during the period from May 8 to August 30, 1902. The 1902 HVPFs were the most hazardous and deadliest activity, since they claimed about 38,000 lives in St. Pierre and vicinity on May 8. In both the 1902 and 1929 eruptions, pyroclastic flow activity decreased in frequency and energy through the course of the eruption, in parallel with decreasing dome extrusion rate Lacroix, 1904 and Perret, 1935. This suggests that pyroclastic flow activity was not principally controlled by external factors, e.g., summit topography or interaction with external water but essentially by surface and nearsurface degassing processes, which included transient explosive phases. The P1 eruptive sequence comprises basal HVPF deposits, which are comparable with the $1902 \mathrm{HVPF}$ deposits in extent and lithologic characters, suggesting they similarly erupted from a growing dome Boudon et al., 1994 and Villemant et al., 1996.

Our sampling covers the range of P1, 1902 and 1929 lithologies (Table 1). The juvenile clasts of the pelean pyroclastic flow deposits consist of various lithologic types encompassing a rather wide range of vesicularities and macroscopic textures. The most abundant lithology is a medium-grey, poorly vesicular lava with highly-crystallized groundmass (crystalline lithic). Subordinate lithologic types are a light-grey dense pumice, and a grey-greenish, almost nonvesicular lava with a crystallized to glassy groundmass (vitreous lithic). Both occur in significant amount (>10 modal\%) in one P1 and some 1902 HVPF units (June 6 to August 30, 1902), while they are virtually absent in the 1902 and 1929 BAF deposits.

\section{Vesicularity (void volume fraction)}

Bulk vesicularities have been obtained by measuring clast weights in air and in water (Archimede's principle). Because most lithologic types contain large vesicles that are open to the outside or interconnected, all clasts were wrapped with known volume and weight of wax film prior to weighing. Finely crushed powders from two different clasts, a pumice from the P1 fallout deposit and a crystalline lithic from a P1 basal HVPF unit had specific weights measured with a pycnometer of $2.61 \pm 0.02$ and $2.69 \pm 0.02 \mathrm{~g} / \mathrm{cm}^{3}$, respectively. We have taken for the porosity calculations a dense-rock specific weight of $2.65 \mathrm{~g} / \mathrm{cm}^{3}$. The vesicularities of about 100 lapilli restricted to the 1-2 cm size range have been measured for each sample. Clasts of larger sizes may have different vesicularity distributions, but we anticipate that these possible size-dependent variations are of second order, as suggested by previous studies on plinian pumices Houghton and Wilson, 1989 and Gardner et al., 1996. The studied rocks are highly porphyritic with modal proportions of phenocrysts ranging between $\sim 35$ and 55 (mean 47) vol.\% on a vesicle-free basis (Martel, 1996), so that bulk vesicularities have been recalculated into matrix vesicularities using a modal proportion of phenocrysts of $47 \mathrm{vol} . \%$ for all lapilli. Matrix vesicularities corresponds to melt vesicularities in case of crystal-free matrix glasses, but may differ significantly from melt vesicularities when the groundmass is crystallized. Matrix crystallization can occur in very different amount from one sample to another in the same deposit (microlite/glass volume ratio from 0 to 1.0, Table 2). 
Table 2. Summary of textural features of the range of pelean (P1, 1902 and 1929) and plinian (P1) lithologies. Microlites form a crystal population, which is well distinct from the phenocrysts in all samples except the dome samples, where the microlites are defined by an arbitrary $<15-\mu \mathrm{m}$ width. Void and microlite apparent sizes and shapes and microlite amounts in groundmass have been estimated for each lithology by visual inspection of a large number of scaled BSE images taken at various magnifications. SEM investigations have been made on a limited number (typically 1 to 5) of thin sections for each lithologyBlank when not determined.

Eruption type

\begin{tabular}{|c|c|c|c|c|c|}
\hline \multirow{2}{*}{$\begin{array}{c}\text { Rock textural type } \\
\text { (lithology) }\end{array}$} & \multicolumn{4}{|c|}{ Pelean } & \multirow{2}{*}{$\begin{array}{l}\text { Plinian } \\
\text { Pumice }\end{array}$} \\
\hline & $\begin{array}{c}\text { Dome } \\
\text { sample }\end{array}$ & $\begin{array}{c}\text { Poorly } \\
\text { vesicular, } \\
\text { crystalline } \\
\text { lithic }\end{array}$ & $\begin{array}{l}\text { Unvesicular } \\
\text { vitreous lithic }\end{array}$ & $\begin{array}{c}\text { Dense } \\
\text { pumice }\end{array}$ & \\
\hline
\end{tabular}

Vesicularity range

(phenocryst-free

basis)

$\begin{array}{llll}5-50 \text { vol.\% } & 5-10 \text { vol. } \% & 45-65 & 50-80 \\ \text { vol. } \% & \text { vol. } \%\end{array}$

Voids apparent size

$\begin{array}{llllll}\text { Isolated } & 1-10 \mu \mathrm{m} & 1-10 \mu \mathrm{m} & 1-20 \mu \mathrm{m} & 1-30 \mu \mathrm{m} & \begin{array}{l}1-100 \\ \mu \mathrm{m}\end{array} \\ \text { Coalesced } & 10-800 & 10-1500 \mu \mathrm{m} & 10-700 \mu \mathrm{m} & \begin{array}{l}20-1000 \\ 20-2000\end{array} & \begin{array}{l}200 \\ \mu \mathrm{m}\end{array}\end{array}$

Microlites/glass vol.

ratio in groundmass

$0.6-0.8 \quad 0.5-1.2 \quad 0-1$

$0.2-0.8 \quad 0-0.2$

(range)

Microlites apparent width

$\begin{array}{llllll}\text { Range } & 2-10 \mu \mathrm{m} & <1-10 \mu \mathrm{m} & <1-7 \mu \mathrm{m} & <1-10 & <1-20 \\ \text { Mean } & 3 \mu \mathrm{m} & 1-3^{\mathrm{a}} \mu \mathrm{m} & 2 \mu \mathrm{m} & 1-3^{\mathrm{a}} \mu \mathrm{m} & 5 \mu \mathrm{m}\end{array}$

Microlites apparent

width/length ratio

$\begin{array}{llllll}\text { Range } & 0.8-0.08 & 0.8-0.05 & 0.8-0.08 & 0.8-0.08 & 1-0.15 \\ \text { Mean } & 0.3 & 0.2-0.3^{\mathrm{a}} & 0.2 & 0.2-0.3^{\mathrm{a}} & 0.3\end{array}$

High-silica phase in groundmass

yes

no

no no

Microfractures

very abundant very abundant abundant

scattered scattered a

Depending on samples. 
Matrix vesicularity and bulk density distributions are shown in Fig. 2. The P1 plinian pumices of the

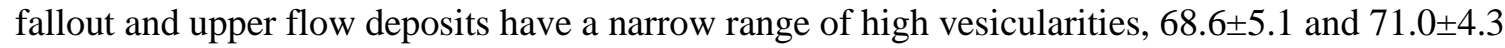
vol. \%, respectively. A subordinate population of fresh, poorly vesicular ( $25.5 \pm 10.8$ vol.\%), crystalline lithics appears as a second mode, accounting for $22 \%$ modal proportion in the upper pumice flow, but is almost absent from the fallout deposit.

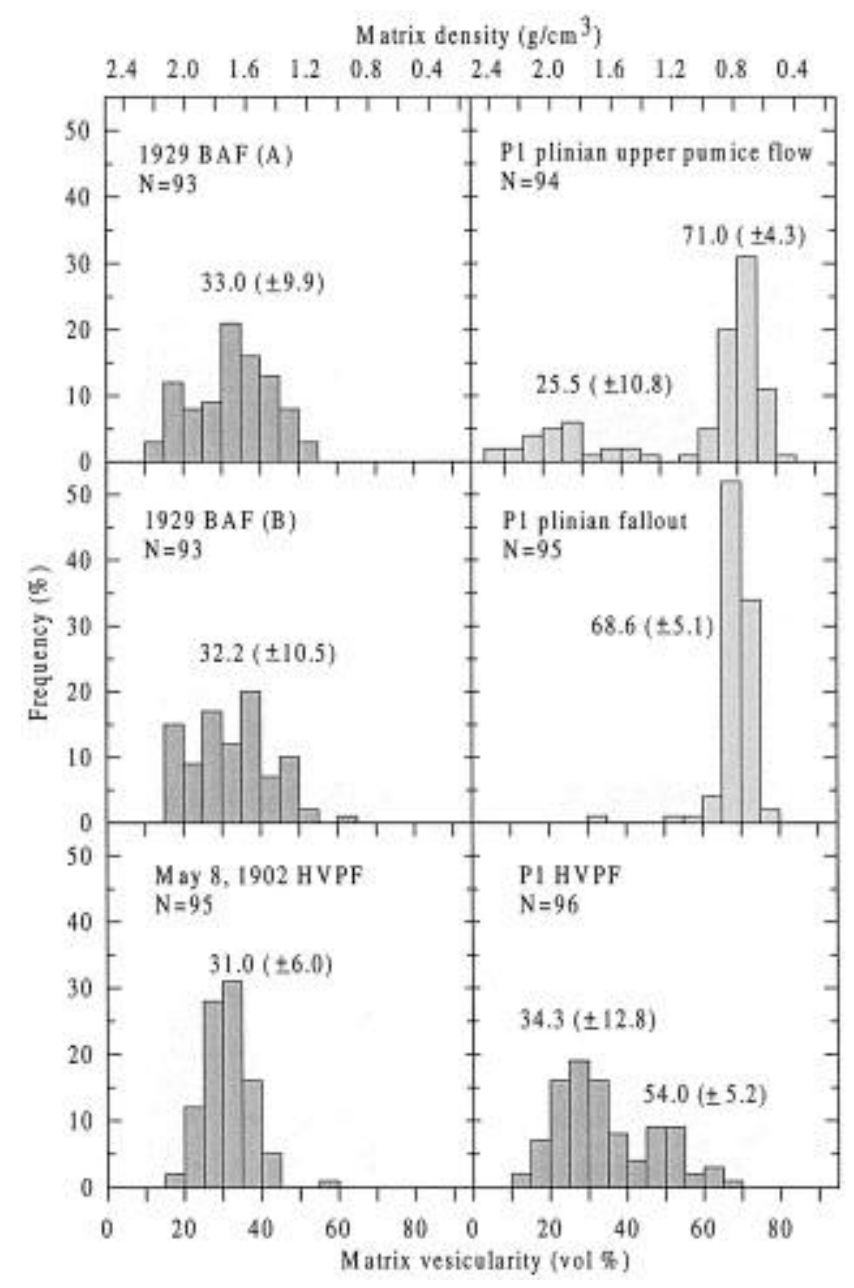

Fig. 2. Density/vesicularity histograms for lapilli $(1-2 \mathrm{~cm})$ from the $P 1,1902$ and 1929 eruptions. $N$ is the number of measured lapilli in each sample. Histograms in dark and light grey refer to pelean and plinian samples, respectively. Densities and vesicularities are recalculated on a phenocryst-free basis. Vesicularity is given as the mean followed by the standard deviation in brackets for the main modes. BAF for block-and-ash flow, HVPF for high-velocity pyroclastic flow.

The 1929 BAF deposits and of the May 8, 1902 HVPF deposit, consisting almost only of crystalline lithic lithology, have a wide distribution of vesicularities, between 5 and 55 vol.\%. The vesicularity range is comparable in the two investigated 1929 BAF deposits, i.e., $33 \pm 9.9$ and $32 \pm 10$ vol.\%. Those deposits are representative in the field of the many 1929 and 1902 BAF units filling the Rivière Blanche valley, but there is no guarantee that all units would have strictly similar vesicularity distributions. The May 8, 1902 lapilli have a narrower, although still broad, matrix vesicularity range and a mean vesicularity comparable with the 
BAF samples (31 \pm 6 vol.\%). Therefore, differences in explosivity and violence of the pelean pyroclastic flows are not necessarily reflected by differences in the clast vesicularities. The P1 HVPF unit, in which we macroscopically distinguish three lithologic types (i.e., crystalline lithics, vitreous lithics and dense pumices) displays a wider vesicularity distribution. The poorly defined secondary mode at $54.0 \pm 5.2$ vol. $\%$ corresponds to the dense pumice population, which forms about $27 \%$ modal proportion of the juvenile clasts.

\section{Microscopic textures}

Textures have been studied using backscattered electron (BSE) imaging and image analysis of selected clasts covering the range of measured vesicularities for each lithologic type. The most significant textural features of the plinian and pelean products are summarised in Table 2 and illustrated in Fig. 3. The sizes that are reported in this section for voids and microlites are apparent long axes. 

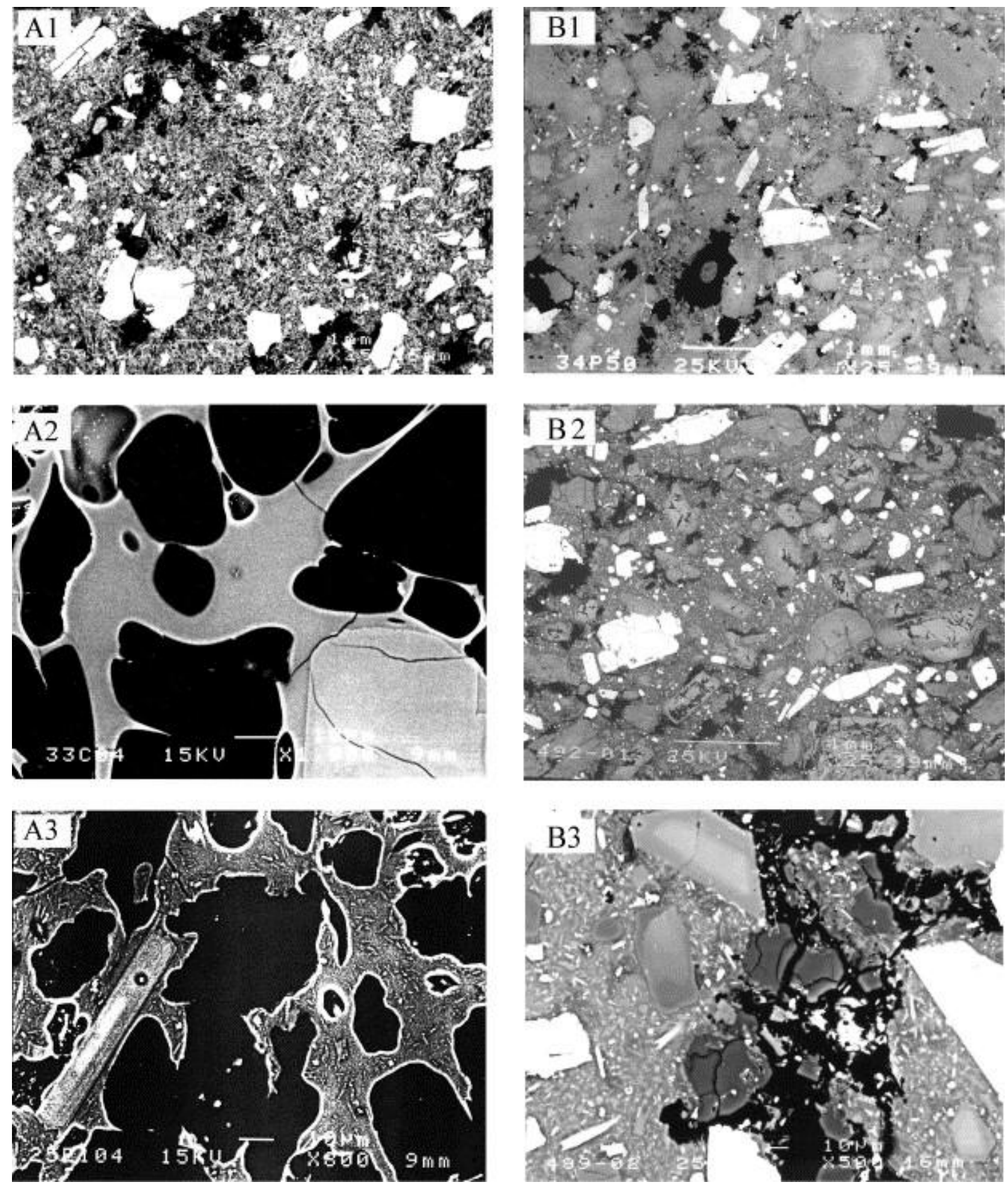

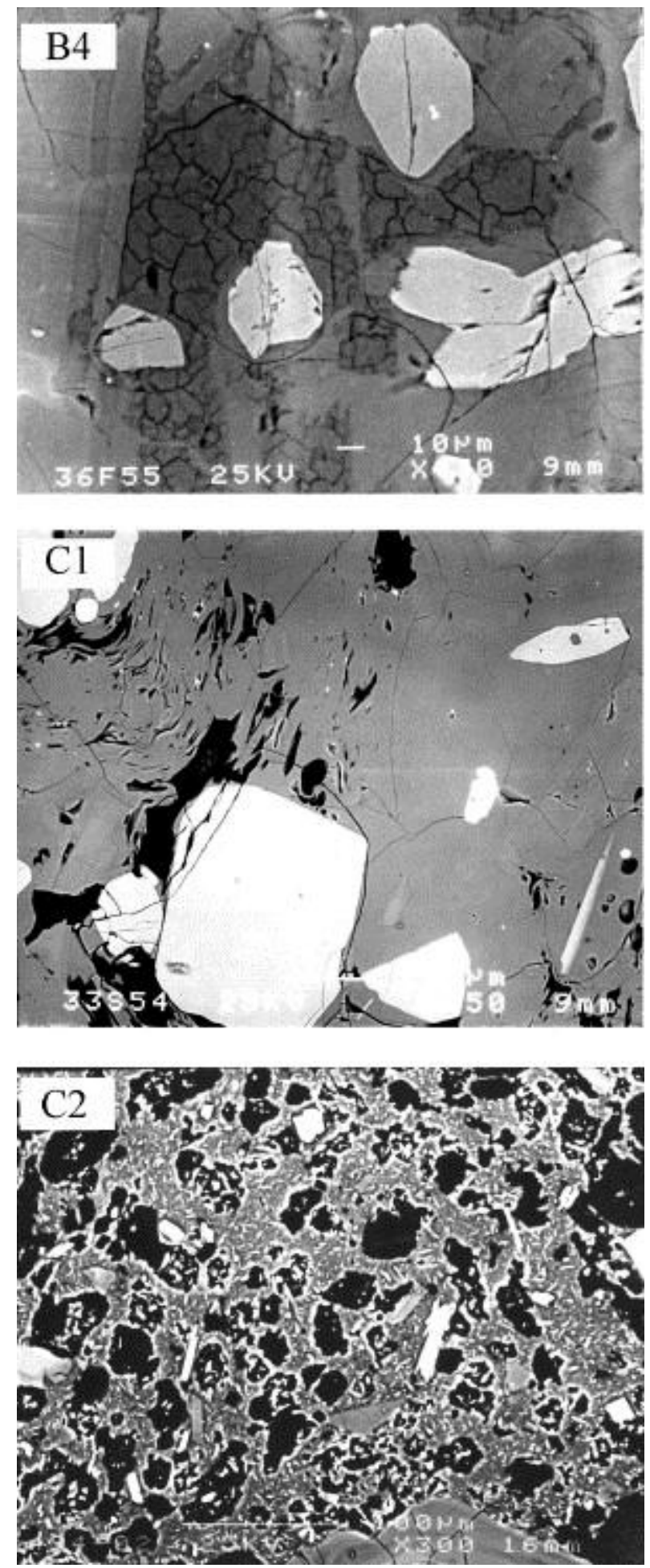

Fig. 3. BSE images showing representative textural features of the plinian and pelean lithologies under study. Crystals appear in white or light grey, glass in dark grey, and voids in black. (A) Plinian fallout pumices: (1) microlite-free [scale bar=1 mm]; (2) microlite-free [scale bar=10 $\mu \mathrm{m}$ ]; (3) microlite-bearing [scale bar=10 $\mu \mathrm{m}$ ]. (B) Pelean crystalline lithics: (1) 1929 dome [scale bar=1 mm]; (2) P1 HVPF (note the phenocryst fractures) [scale bar=1 mm]; (3) May 8, 1902 (note the fractured cristobalite pieces in dark grey) [scale bar $=10 \mu \mathrm{m}$ ]; (4) $1929 \mathrm{BAF}$ (note the fractured cristobalite areas in dark grey) [scale bar=10 $\mu \mathrm{m}$ ]. (C) Subordinate lithologies: (1) vitreous lithic of P1 HVPF [scale bar=100 $\mu \mathrm{m}$ ]; (2) dense pumice of P1 HVPF (note the microlites) [scale bar=100 $\mu \mathrm{m}$ ]. 
Qualitative observation of BSE images of plinian pumices from both the P1 fallout and upper pumice flow units reveals a polymodal vesicle size distribution. One vesicle population consists of unevenly-distributed large $(>100 \mu \mathrm{m})$ vesicles of irregular shape, preferentially developed along phenocrysts (Fig. 3A1). They apparently result from bubble coalescence, as suggested by frequent wall remnants of former smaller bubbles around them (Fig. 3A2). The estimated size of the main vesicle population is $\sim 5-80 \mu \mathrm{m}$, with a peak at $\sim 10-20 \mu \mathrm{m}$ (Fig. $3 \mathrm{~A} 2, \mathrm{~A} 3)$. Bubbles are dominantly coalesced in this population too. The groundmass of the P1 pumices is either microlite-free (Fig. 3A2) or microlite-bearing (Fig. 3A3) with up to 20 vol.\% microlites on a bubble-free basis (determined by image analysis). Microlite-bearing pumices cover virtually the whole range of $\mathrm{P} 1$ pumice vesicularities. We did not observe systematic differences in vesicularity and vesicle texture between the microlite-free and microlite-bearing pumices as described in some other plinian eruptions, e.g., the May 18, 1980 plinian phase at Mount St. Helens (Klug and Cashman, 1994).

Samples from the 1902 and 1929 domes have microscopic textures comparable to the crystalline lithics of the pelean pyroclastic flow deposits (Fig. 3B1, B2). Most voids have sizes in the range $5-100 \mu \mathrm{m}$, but some are up to $1500 \mu \mathrm{m}$. The voids are unevenly distributed, irregular and angular in shape, and tend to be more abundant along the margins of phenocrysts. Some voids develop along randomly oriented fractures, which cross-cut the groundmass and the phenocrysts. Smaller isolated voids, $1-10 \mu \mathrm{m}$ in size, are either angular or subrounded. Some coalescence forms voids typically $20-30 \mu \mathrm{m}$ in size. At vesicularity higher than $\sim 40$ vol. $\%$, large $(>500 \mu \mathrm{m})$ irregular voids are more abundant and voids $<200$ $\mu \mathrm{m}$ are more rounded. Phenocrysts can contain irregular voids as large as $100 \mu \mathrm{m}$ or subrounded voids of a few microns, which are sometimes connected to the outside of the crystal (Fig. 3B2). Many phenocrysts of the dome and crystalline lithics are cut by large, irregular fractures (Fig. 3B1, B2), along which relative displacements and jigsaw-fit figures are often visible.

The groundmasses of the dome and crystalline lithic lithologies are rich in microlites (50 vol.\% on Fig. 3B3, determined by image analysis), which average sizes range from a couple of microns to $\sim 50 \mu \mathrm{m}$. No systematic difference in microlite density, shape and size appears between crystalline lithics from the BAFs and the HVPFs. The pelean microlites are in general slightly larger and more equant than the plinian ones (comparing Fig. 3B3 with Fig. 3A3). The groundmass of the dome and the pyroclastic flow samples (especially the poorlyvesicular lithics) also contains a pervasive high-silica phase, identified as cristobalite by Raman spectroscopy (Fig. 3B3, B4). This high-silica phase occupies parts of the former voids or appears as heterogeneously-distributed areas with a typical cracked appearance. Crystalline silica also occurs as dispersed patches of a few microns or tens of microns, encased in the groundmass with irregular contacts against glass and microlites. The abundance of the highsilica phase in the groundmass varies greatly among the section examined and even from place to place within a given thin section. It seems systematically present in the dome samples and in the less vesicular lithic clasts, whereas it is much less abundant in more vesicular lithic clasts (melt vesicularity >0.3), and apparently absent in some vesicular lithic clasts (melt vesicularity of 0.38 ).

The two subordinate pelean lithologies, i.e., the vitreous lithics (Fig. 3C1) and the dense pumices (Fig. 3C2), are mostly distinct from the crystalline lithic lithology by their vesicularities and void textures. The voids of the vitreous lithics are similar to those of the crystalline lithics in sizes and coalescence features, but they are much less abundant. They are very evenly distributed, areas up to $100 \mathrm{~mm}^{2}$ not containing any void while elsewhere are 
clusters of either isolated or coalesced void with mostly subrounded and often elongated shapes. The dense pumices have vesicle sizes and density intermediate between the lithic lithologies and the plinian pumices. Quite unexpectedly, dense pumices are rather similar to the crystalline lithics with regard to the microlite sizes, shapes, and amounts (microlite/glass volume ratio between 0.2 and $0.8,0.6$ on Fig. 3C2). The vitreous lithics, although apparently glassy to the naked eye, can contain microlites. Both subordinate lithologies are devoid of the high-silica phase in the groundmass.

\section{Glass compositions}

Glass analyses were performed on a Cameca SX50 (CNRS-BRGM, Orléans) under the following conditions: $6 \mathrm{nA}$ sample current, $15 \mathrm{kV}$ accelerating voltage, $10 \mathrm{~s}$ counting time and 5 or $10 \mu \mathrm{m}$ beam size. Glass analyses were corrected for alkali loss (Pichavant, 1987). The glass compositions are shown on Fig. 4.

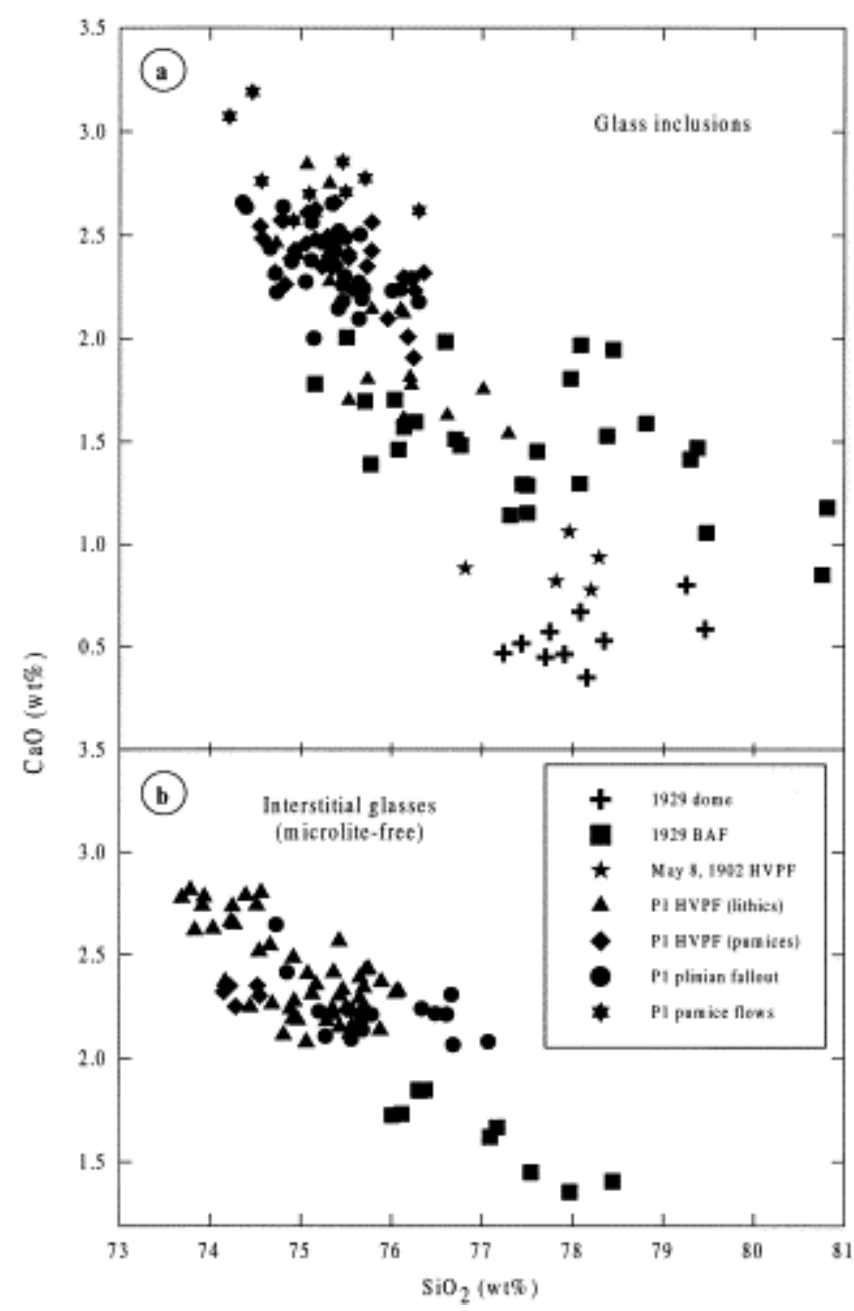

Fig. 4. Compositions of glasses in a $\mathrm{CaO}$ versus $\mathrm{SiO}_{2}$ wt.\% diagram. (a) glass inclusions and (b) matrix glasses. Analytical conditions and errors for microprobe analyses given in text. Sums of oxides are recalculated to 100 (anhydrous basis). Analysed matrix glasses pertain to microlite-devoid or virtually devoid samples only. 


\subsection{Compositions of the glass inclusions}

In both plinian and pelean samples, inclusions are rhyolitic in composition (74-81 wt.\% $\mathrm{SiO}_{2}$ ), 5 to $80 \mu \mathrm{m}$ in size, with an approximate mean of $20 \mu \mathrm{m}$, and are found in plagioclase or orthopyroxene phenocrysts. The inclusions show no systematic correlation with the composition of the host crystal, suggesting there were no significant post-entrapment chemical reactions with the crystal. The plinian inclusions are glassy, have clear contact with the host crystal and a narrow compositional range (74-76 wt.\% $\mathrm{SiO}_{2}$ ). In the pelean samples, especially in the dome samples, most of the inclusions are devitrified and surrounded by fractures. The compositions of the pelean glass inclusions vary over a wider range than in the plinian pumices (74-81 wt.\% $\mathrm{SiO}_{2}$ ), some overlapping with the plinian compositions (P1 HVPF pumices and some crystalline lithics from 1929 BAFs and P1 HVPF) while others are distinctly more differentiated (1929 dome and May 8, 1902 HVPF). These highly differentiated pelean inclusions $\left(>77 \mathrm{wt} . \% \mathrm{SiO}_{2}\right)$ are interpreted as resulting from the devitrification, therefore no more representative of the pre-eruptive melt. The compositions of glass inclusions are found to vary between lithologies (pumice versus lithic) rather than between eruptive style.

\subsection{Compositions of the matrix glasses}

The matrix glasses from plinian material were analysed in microlite-free or microlite-poor $(<10$ vol.\%) pumice lumps. Matrix glasses could not be analysed in some pelean samples because of the small size of glass areas (e.g., domes, May 8, 1902, and most 1929 crystalline lithics). All matrix glasses have rhyolitic compositions. The matrix glass compositions from the P1 plinian fallout pumices (75-77 wt. $\% \mathrm{SiO}_{2}$ ) compare with those from P1 pelean, microlite-poor, lithics and dense pumices (74-76 wt.\% $\mathrm{SiO}_{2}$ ). Matrix glass compositions are in the range of the plinian glass inclusions (74-76 wt.\% $\mathrm{SiO}_{2}$ ). Matrix glasses from the 1929 BAFs are more evolved than the P1 ones, reflecting higher crystallinity of the groundmass in the analysed samples.

\section{Glass water content}

\subsection{Analytical methods}

Near-infrared spectroscopy was used for the water determination in glasses (accuracy $<0.2$ wt.\%, Devine et al., 1995). Glass densities were obtained by glass weights in air and water (Archimede's principle). Water concentrations are determined using the Lambert-Beer law (Stolper, 1982). Three standard glasses were prepared to determine the absorption coefficients, which are dependent on anhydrous glass composition and water content (Behrens et al., 1996). We separated the matrix (phenocryst-free) from the $\mathrm{P} 1$ plinian fallout pumice (matrix dry-composition: $70.98 \mathrm{SiO}_{2}, 2.28 \mathrm{FeO}, 4.07 \mathrm{Na}_{2} \mathrm{O}, 1.64 \mathrm{~K}_{2} \mathrm{O}, 16.19 \mathrm{Al}_{2} \mathrm{O}_{3}, 0.11$ $\mathrm{MnO}, 0.41 \mathrm{MgO}, 4.45 \mathrm{CaO}, 0.24 \mathrm{TiO}_{2} \mathrm{wt} . \%$ ) and hydrated the glass in an internally heated pressure vessel at $1300^{\circ} \mathrm{C}$ and $4 \mathrm{~kb}$. The three standard glasses contain 1.99, 4.59 and 6.33 $\mathrm{H}_{2} \mathrm{O}$ wt.\% (precision of 0.15 wt.\%), measured by Karl-Fischer titration following the procedure of Westrich (1987). We determined absorption coefficients for molecular water and hydroxyl groups of 1.47 and $1.37 \mathrm{l} / \mathrm{mol} / \mathrm{cm}$, respectively, in agreement with previous determinations for rhyolitic or albitic glasses Newman et al., 1986, Silver and Stolper, 1989 and Behrens et al., 1996. 
Unfortunately, near-infrared spectroscopy could not be used as a routine method because of the small sizes of the glass areas (generally around $20 \mu \mathrm{m}$ in diameter). Nevertheless, the few spectra obtained show that volatiles are nearly pure water. Glass water contents were routinely measured by an improved "by-difference" method using the electron microprobe (Devine et al., 1995). To be a valid method, the deficiency to $100 \%$ of the electron microprobe analyses has to be corrected for alkali loss (Pichavant, 1987) and the analyses have to be calibrated against standard glasses with the same compositions than the samples. Therefore, the three standard glasses described above were analysed together with the samples in each microprobe session. The $100 \%$ deficiencies of the samples were calibrated on the standard glasses (water content previously determined by Karl-Fischer titration) and attributed to their water content. Uncertainties of our glass water determinations are \pm 0.5 wt.\%.

\subsection{Water contents of glass inclusions}

The water contents of glass inclusions are given by lithologic type in Table 3 and displayed on Fig. 5. No correlation has been found between the host crystal composition and the water content of the glass inclusions (Fig. 6). Glass inclusions from the P1 plinian pumices have average $\mathrm{H}_{2} \mathrm{O}$ contents of $5.8 \pm 0.7 \mathrm{w} \%$ in the fallout deposit and $5.5 \pm 1.5 \mathrm{wt}$.\% in the upper pumice flow unit. These average values are in the range of the experimentally-constrained pre-eruptive melt water content of 5.3-6.3 wt.\% (Martel et al., 1998). A single analysis by infrared spectroscopy on a glass inclusion from the P1 fallout deposit, yielding $6.7 \pm 0.5 \mathrm{wt} . \%$ $\mathrm{H}_{2} \mathrm{O}$, falls in the range of microprobe analyses. There is a large dispersion, however, around the average values. Water contents lower than $5 \mathrm{wt} . \%$ do exist, as well as values higher than $6.5 \mathrm{wt} . \%$, up to $7.8 \mathrm{wt} . \%$. 
Table 3. Water contents of glass inclusions and matrix glasses of the range of pelean and plinian lithologies. Analyses were all obtained by an improved by-difference method according to methodology and analytical conditions given in textBAF for block-and-ash flow; HVPF for high-velocity pyroclastic flow.

\begin{tabular}{|c|c|c|c|c|c|c|c|}
\hline \multirow[b]{2}{*}{$\begin{array}{c}\text { Eruption } \\
\text { type }\end{array}$} & \multirow[b]{2}{*}{$\begin{array}{c}\text { Sample } \\
\text { textural and } \\
\text { eruptive unit }\end{array}$} & \multicolumn{3}{|c|}{ Glass inclusions } & \multicolumn{3}{|c|}{ Matrix glasses } \\
\hline & & $\begin{array}{c}\text { Number } \\
\text { of } \\
\text { analyses }\end{array}$ & $\begin{array}{c}\mathrm{H}_{2} \mathrm{O} \\
\text { wt. } \% \pm \sigma\end{array}$ & $\begin{array}{c}\mathrm{H}_{2} \mathrm{O} \\
\text { wt.\% } \\
\text { total } \\
\text { range }\end{array}$ & $\begin{array}{c}\text { Number } \\
\text { of } \\
\text { analyses }\end{array}$ & $\begin{array}{c}\mathrm{H}_{2} \mathrm{O} \\
\text { wt. } \% \pm \sigma\end{array}$ & $\begin{array}{c}\mathrm{H}_{2} \mathrm{O} \\
\text { wt. \% } \\
\text { total } \\
\text { range }\end{array}$ \\
\hline \multirow[b]{2}{*}{ Plinian } & $\begin{array}{l}\text { pumices, } \mathrm{P} 1 \\
\text { plinian fallout }\end{array}$ & 14 & $5.8 \pm 0.7$ & $4.3-7.1$ & 4 & $1.8 \pm 0.3$ & $1.6-2.3$ \\
\hline & $\begin{array}{l}\text { pumices, } \mathrm{P} 1 \\
\text { upper pumice } \\
\text { flow }\end{array}$ & 10 & $5.5 \pm 1.5$ & $3.0-7.8$ & 5 & $3.1 \pm 0.4^{\mathrm{a}}$ & $2.8-3.8^{\mathrm{a}}$ \\
\hline \multirow{5}{*}{ Pelean } & $\begin{array}{l}1929 \text { dome } \\
\text { crystalline }\end{array}$ & 10 & $0.3 \pm 0.8$ & $0.0-2.6$ & 0 & - & - \\
\hline & $\begin{array}{l}\text { lithics } 1929 \\
\text { BAF } \\
\text { crystalline }\end{array}$ & 18 & $0.2 \pm 0.6$ & $0.0-2.0$ & 1 & 0.0 & - \\
\hline & $\begin{array}{l}\text { crystalline } \\
\text { lithics, May 8, } \\
1902 \text { HPVF }\end{array}$ & & $1.6 \pm 0.8$ & $0.9-2.5$ & 0 & - & - \\
\hline & $\begin{array}{l}\text { glassy lithics, } \\
\text { P1 HPVF } 2 \\
\text { dense }\end{array}$ & 14 & $2.7 \pm 1.9$ & $0.4-7.1$ & 20 & $0.1 \pm 0.3$ & $0.0-1.3$ \\
\hline & $\begin{array}{l}\text { pumices, P1 } \\
\text { HPVF } 2\end{array}$ & 28 & $5.1 \pm 1.1$ & $2.2-6.9$ & 11 & $0.4 \pm 0.7$ & $0.0-1.8$ \\
\hline
\end{tabular}




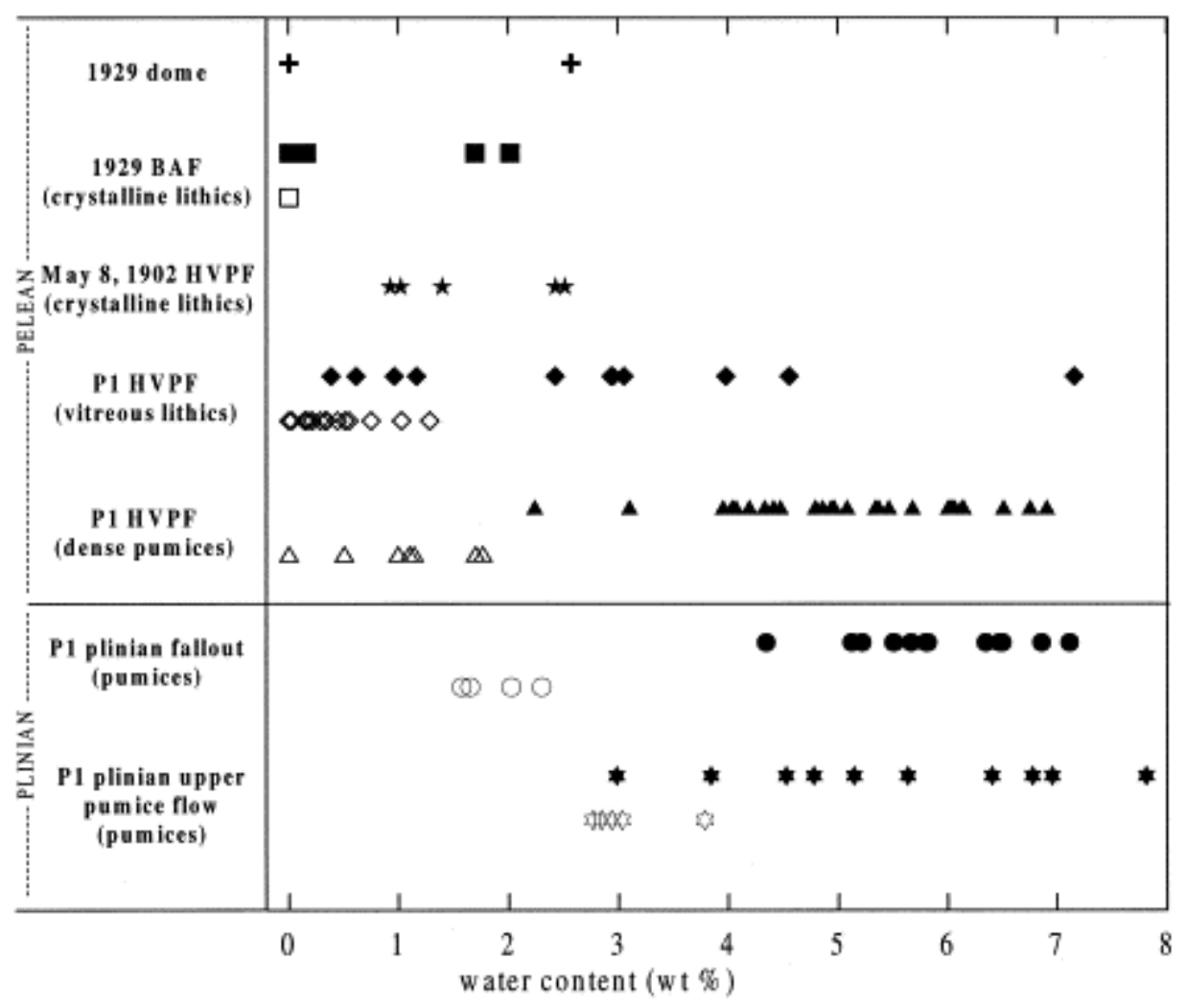

Fig. 5. Water contents of glasses of the different pelean and plinian lithologies under study. For each lithology, filled symbols (upper line) are glass inclusions, and open symbols (lower line) are matrix glasses. BAF for block-and-ash flow, HVPF for high-velocity pyroclastic flow. 


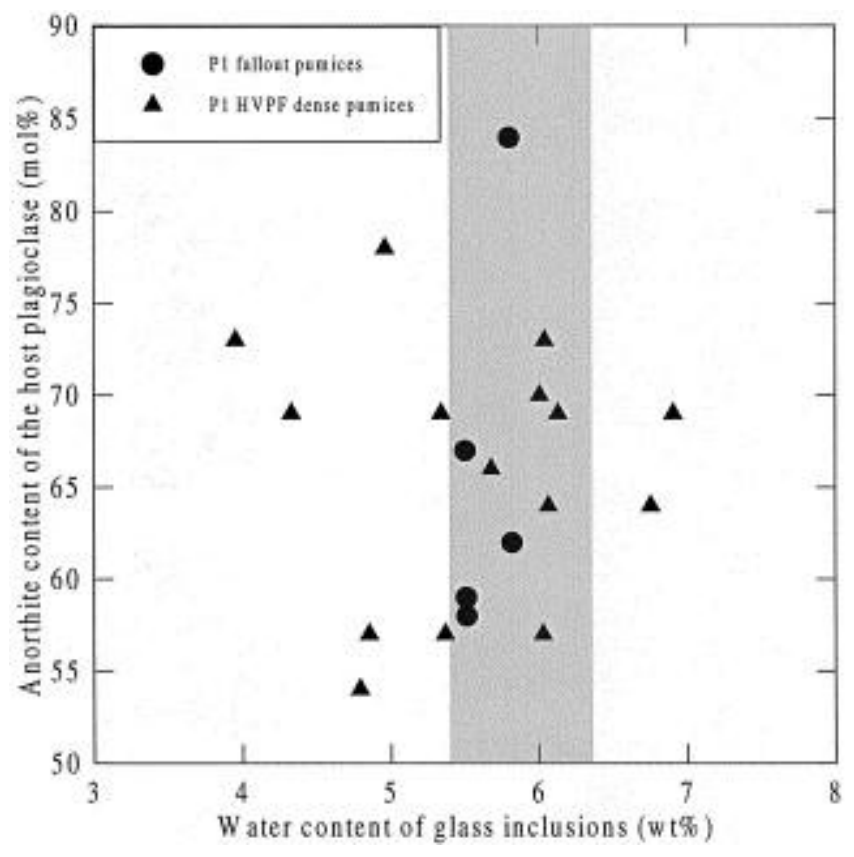

Fig. 6. Water contents of glass inclusions versus the composition of neighboring plagioclase for two selected lithologies, the plinian pumices from the P1 fallout (circles) and the pelean dense pumices from the P1 HVPF (triangles). Plagioclase has been analysed less than 5 microns away from the glass inclusion. Analytical errors on the anorthite and water determinations are of $\pm 1 \mathrm{~mol} . \%$ and \pm 0.5 wt. $\%$, respectively.

Glass inclusions from the pelean products have generally lower $\mathrm{H}_{2} \mathrm{O}$ contents than the plinian products. There are strong variations depending on the lithologic type and the eruptive unit (Table 3; Fig. 5). Glass inclusions from the 1929 dome and the crystalline lithics from one 1929 BAF are almost dry. Glass inclusions of the crystalline lithics from the May 8, 1902 HVPF have notably higher water contents, $1.6 \pm 0.8 \mathrm{wt} . \%$. Those of vitreous lithics from one P1 HVPF unit have a very large range of water concentrations $(2.7 \pm 1.9 \mathrm{wt} . \%)$, with some values as high as in the plinian products. The dense pumice lithology from the same P1 HVPF unit contrasts strongly with all other pelean lithologies since average water concentrations (5.1 $\pm 1.1 \mathrm{wt} . \%)$ nearly reach those of the plinian pumices, although variation is larger than in the plinian pumices and values down to $2.2 \mathrm{wt} . \%$ also occur.

\subsection{Water contents of matrix glasses}

Rehydration processes by meteoric or hydrothermal water, which are often suspected to have modified matrix glass compositions after eruption, can be excluded for the samples under this study on the basis of $\mathrm{Cl} / \mathrm{H}_{2} \mathrm{O}$ and $\delta \mathrm{D}$ measurements (Villemant and Boudon, 1998), except for the P1 pumice flow matrix glasses that will not be further considered $\left(\delta \mathrm{D}\right.$ and $\delta^{18} \mathrm{O}$ data, Rahaingoson and Agrinier, personal communication). The water contents of matrix glasses are given by lithologic type in Table 3 and displayed on Fig. 5. 
The water contents show a narrow range, $1.8 \pm 0.3 \mathrm{wt} . \%$ in the plinian fallout deposit. The few analyses of matrix glasses in the 1929 products indicate virtually dry glasses within analytical error. Matrix glasses could not be analysed in similar lithology from the May 8, 1902 HVPF unit. The matrix glasses of the P1 HVPF vitreous lithic and dense pumice lithologies have water contents of $0.1 \pm 0.3$ and $0.4 \pm 0.7$ wt. $\%$, respectively. The HVPF dense pumice lithology contrasts with the plinian pumices by much lower water contents in the matrix glasses.

\section{Microlite compositions}

The microlite phases in all lithologies are orthopyroxenes, oxides, and dominant plagioclases. Although the microlite compositions were not thoroughly investigated in this study, some microlite analyses are presented in Fig. 7, showing rather large intra-lithology and interlithology compositional variations. Plagioclase and orthopyroxene microlites from the plinian P1 pumices have higher anorthite and enstatite contents, respectively, than the phenocryst rim compositions assumed to best reflect the conditions in the magma chamber prior to eruption Martel et al., 1998 and Gourgaud, 1985. This contrasts, for instance, with data reported for pumices from the plinian phase of the Mount St. Helens 1980 eruption of whose plagioclase microlites are more albitic than the phenocryst rims Scheidegger et al., 1982 and Cashman, 1992. This contrasts also with the microlite compositions we obtain on the pelean products, which apparently span compositional ranges poorer in anorthite and enstatite mol\%. Overall, these preliminary results suggest that there may be systematic differences in microlite compositions among the plinian and pelean lithologies that presumably reflect differences in physico-chemical conditions of the microlite crystallization in response to the degassing processes. 


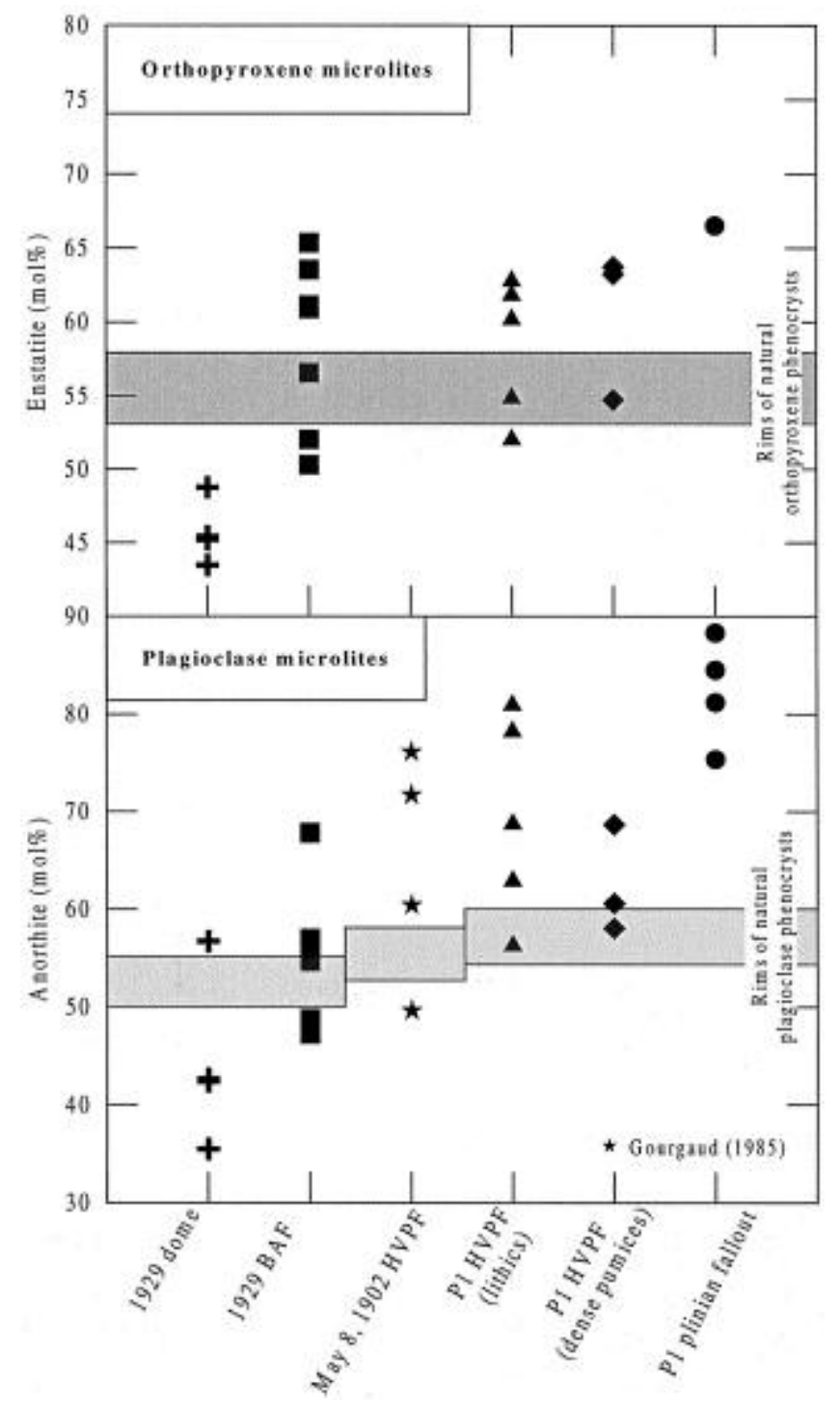

Fig. 7. Compositions of microlites of plagioclase and orthopyroxene in various plinian and pelean lithologies. Phenocryst rim compositions (Martel et al., 1998) are shown for comparison. BAF for block-and-ash flow, HVPF for high-velocity pyroclastic flow. 


\section{Discussion}

\subsection{Pre-eruptive water content}

Trapped melt inclusions in phenocrysts are often used to infer pre-eruptive melt water contents, by assuming that glass inclusions have been closed systems since liquid entrapment and thus record the original volatile concentrations of the trapped melt (e.g., Anderson et al., 1989 and Hervig et al., 1989. In this study, the average water content of the glass inclusions from the P1 plinian pumices, i.e., 5.8 $\pm 0.7 \mathrm{wt} . \%$, leads to a good agreement with the experimental pre-eruptive estimate of the melt $\mathrm{H}_{2} \mathrm{O}$ content (5.3-6.3 wt.\%, Martel et al., 1998) determined by reproducing the natural phase assemblage and phenocryst rim compositions. Water contents in glass inclusions from other plinian eruptions show variations comparable to our P1 data, and are also in good agreement with the pre-eruptive water content predicted by experimental and petrological constraints (e.g., at Mount St. Helens and Pinatubo, see review by Johnson et al., 1994). At Mount Pelée, the highest measured water concentrations in glass inclusions is 1 to $2 \mathrm{wt} . \%$ above the pre-eruptive water content and could correspond to water heterogeneities in the magma storage system. The low water contents ( $<5 \mathrm{wt} . \%)$ of most of the glass inclusions of the pelean products cannot be reconciled with the pre-eruptive melt water concentration deduced experimentally. Further, the different lithologies among the pelean products yield very contrasted water contents. Obviously, the water contents in glass inclusions from our pelean products would not be reliable to assess a pre-eruptive melt water concentration, probably due to significant post-entrapment leakage. As theoretically suggested by Tait (1992), the water in glass may exsolve in response to decompression during magma ascent. Because the host crystal can hardly sustain elastic deformation, it may not be able to accommodate the decompression-induced expansion of the inclusion and consequently fracture. The available data therefore suggest that plinian pumices may be in most cases a suitable material for preservation of melt inclusions, presumably owing to short transit times from the chamber to the atmosphere, as well as short cooling times allowing a rapid quench of the melt inclusions, while pelean material is much prone to leakage of melt inclusions.

\subsection{Water exsolution and vesiculation during magma ascent}

The amount of exsolved water between the magma chamber and the quench level (glass transition temperature) is given by the difference between the water content in the magma chamber and in the matrix glass (assuming no post-depositional hydration). In plinian eruptions, the time scale between fragmentation and quenching in the atmosphere is of the order of seconds, so that water diffusion into bubbles above the fragmentation level can be neglected (Thomas et al., 1994). Therefore, the water content of the matrix glass of the pumice clots closely represents the residual dissolved water content in the melt at the fragmentation level. This assumption is implicit in most theoretical models of plinian eruption dynamics, and the same assumption can be as well applied to pyroclasts from dome eruptions. Part of the magma, however, may be quenched below the fragmentation level, due for instance to strong cooling gradients along the conduit wall. Water-bearing obsidian clasts present in subordinate amount in some plinian tephra have been interpreted as juvenile, partially and variably degassed magma due to variable cooling rates along the conduit walls Eichelberger and Westrich, 1981, Newman et al., 1988, Dunbar and Kyle, 1992 and Bursik, 1993. 
In current theoretical models of magma ascent in explosive eruptions, the residual water content of the melt at the fragmentation level is an output parameter derived by making assumptions on the fragmentation conditions, generally by fixing a vesicularity threshold of the magma. This approach is potentially circular and prone to flaws in the current state of knowledge of the processes and conditions of explosive magma fragmentation. The frequent assumption that magma vesicularity is quenched at the fragmentation level (i.e., the vesicularity measured in the pyroclasts represents that at fragmentation) is not always true, as bubbles might expand significantly above the fragmentation level within the cooling time Thomas et al., 1994 and Gardner et al., 1996. In this study, the melt water content at fragmentation is provided by the $\mathrm{H}_{2} \mathrm{O}$ determinations in matrix glasses and the difference with the pre-eruptive water content (experimentally-constrained as 5.3-6.3 wt.\%) gives a direct estimate of the amount of exsolved water during ascent of the magma up to the fragmentation level. The vesicularity $(\alpha)$ just before fragmentation, assuming a degassing in closed-system (the exsolved water vapour remains in contact with the melt) and in equilibrium (the melt water content is the water solubility at a given pressure), is given by $\alpha=1 /\left\{1+\left[\rho_{\mathrm{g}} /\left(\left(x_{(\mathrm{Pi})}-x_{(\mathrm{Pe})}\right) \rho_{1}\right)\right]\right\}$, where $\rho_{\mathrm{g}}$ and $\rho_{\mathrm{l}}$ are the gas and melt densities, respectively, $x_{(\mathrm{Pi})}$ and $x_{(\mathrm{Pe})}$ the water solubility at the initial and eruptive pressure (Jaupart and Tait, 1990). For $\rho_{\mathrm{m}}$ of $2.45 \mathrm{~g} / \mathrm{cm}^{3}, x_{(\mathrm{Pi})}$ of $5.8 \pm 0.7 \mathrm{wt} . \%$ (pre-eruptive water content), a gas density calculated after Haar et al. (1984) at $900^{\circ} \mathrm{C}$, and $x_{(\mathrm{Pe})}$ as the water content measured in the matrix glasses, we calculate vesicularities that are compared to the measured porosities in the plinian and pelean products (Fig. 8), The calculated melt vesicularities for the plinian P1 fallout pumices are $69 \pm 5 \mathrm{vol} . \%$ for a $x_{(\mathrm{Pe})}$ of $1.8 \mathrm{wt} . \%$. This is in agreement with the measured porosities (71 \pm 4 vol.\%), thus consistent with a degassing as a closed-system in near-equilibrium up to the fragmentation level for the P1 plinian phase. This also implies that the pumice lapilli (1-2 $\mathrm{cm}$ in diameter) did not expand significantly after fragmentation. By contrast, the nearly dry matrix glasses of the 1929 products, suggesting equilibration of the residual liquid with near atmospheric pressure (consistent with its inability for explosive fragmentation) lead to calculated vesicularities $\sim 100$ vol. $\%$, whereas the average measured porosities range from $\sim 33$ vol.\% (up to $\sim 70$ vol.\% for the most crystallized matrix, i.e., microlite/glass ratio of 1.2, Table 2). The low residual water contents of the pelean P1 HPVF, i.e., $0.1 \mathrm{wt} . \%$ for the glassy lithics and $0.4 \mathrm{wt} . \%$ for the dense pumices, lead to calculated melt vesicularities $>98$ vol. $\%$, whereas the measured porosities are $34 \pm 13$ and $54 \pm 5$ vol.\% (up to $\sim 97 \mathrm{vol} . \%$ for the maximum microlite/glass ratio of 0.8 ; Table 2), respectively. Even the $\mathrm{H}_{2} \mathrm{O}$-richest glasses of the P1 dense pumices $(1.8 \mathrm{wt} . \%$ ) lead to calculated vesicularities of $71 \pm 4 \mathrm{vol} . \%$, which are higher than the $50 \pm 5$ vol.\% measured porosity. 


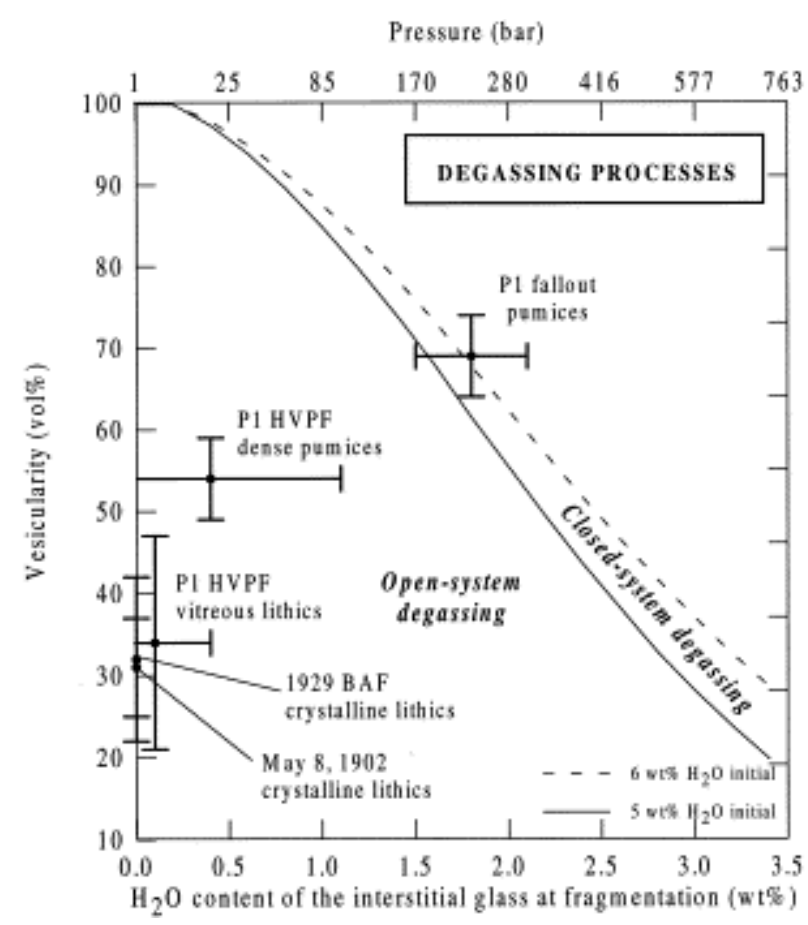

Fig. 8. Degassing processes. The curves represent the theoretical melt vesicularities as a function of the matrix melt $\mathrm{H}_{2} \mathrm{O}$ content at fragmentation (fragmentation pressure at $900^{\circ} \mathrm{C}$ given by the upper abscissa axis (Burnham (1979)), calculated after Jaupart and Tait (1990) for initial (pre-eruptive) melt water contents of 5 and 6 wt. $\% 900^{\circ} \mathrm{C}$, and water state equation of Haar et al. (1984), assuming a closed-system near-equilibrium degassing. The points are the measured matrix vesicularities (Fig. 2) as a function of the whole range of water content measured in the matrix glass (Table 3 ) for the plinian and pelean lithologies of Mount Pelée. BAF for block-and-ash flow, HVPF for high-velocity pyroclastic flow.

\subsection{Mechanism for open- and closed-system degassing}

The low residual water contents, low groundmass vesicularities and extensive groundmass crystallization of the pelean products are direct evidence of open-system degassing above the magma reservoir. Open-system gas loss requires a gas flow from bubbles out of the magma column into the basement rocks or upward through the conduit (Eichelberger et al., 1986), which is directly related to the relative magma/conduit permeabilities and the magma ascent rate. Experiments of gas transfer through magma attempting to approach the in-situ conditions (Westrich and Eichelberger, 1994) suggest that a rhyolitic melt becomes permeable to gas flow in the porosity range of 60-70 vol. \%, consistent with the strong permeability increase at porosities of 60-70 vol.\% reported by Eichelberger et al., 1986 in pyroclastic samples. The plinian pumices certainly reached porosities of $60 \mathrm{vol} . \%$, at which they were potentially permeable, but they did not lose their exsolved water, probably because of fast ascent rates. In contrary, probably because of low ascent rates, the pelean magmas extensively lost their vapour, so that they must have reached vesicularities around $60 \mathrm{vol} \%$, although the final products have typical porosities of 30-35 vol.\%. The pelean products may have undergone a two-stage vesiculation, evidenced by the silica-bearing and silica-free vesicles. Similar textural evidence for two vesiculation stages has been documented in the Mount St. Helens 1980 blast dacite, the first one leading to gas loss through magma permeability (Hoblitt and 
Harmon, 1993). The silica-bearing vesicles could be a remnant evidence for the open-system degassing, while reaching porosities of $\sim 60$ vol. $\%$.

\section{Conclusions}

Petrological studies and phase equilibrium experiments have already shown that differences in eruptive regime at Mount Pelée volcano are not related to differences in pre-eruptive water content (Martel et al., 1998), but must be ascribed to differences in degassing conditions during magma ascent, the plinian eruptions possibly approaching closed-system degassing while the pelean regime obviously requires open-system gas loss in the conduit Villemant et al., 1996, Martel et al., 1998 and Villemant and Boudon, 1998. In this study, pelean and plinian andesite lithologies from the most recent eruptions of Mount Pelée have been investigated for glass composition and water content, microtextures, and vesicularities in order to get information on the degassing processes during magma ascent and the bifurcation between the plinian and pelean regimes. The main conclusions are as follows:

(1) The pelean products include a wide range of lithologies that differ markedly in bulk vesicularity, glass water contents and microtextural features. They reflect variations in degassing history even within the same eruption. By contrast, the plinian pumices are much more homogeneous and reflect more uniform conditions upon magma ascent and eruption.

(2) The plinian glass inclusions ably reflect the pre-eruptive melt water content, whereas the pelean inclusions indicate water leakage.

(3) Melt vesicularities calculated from the amount of exsolved water compare with the measured matrix vesicularities for the plinian pumices and are consistent with closed-system, near-equilibrium degassing up to the fragmentation in the P1 plinian phase.

(4) The low residual water contents, low groundmass vesicularities and extensive groundmass crystallization of the pelean products are direct evidence of open-system degassing during magma ascent, occurring during the first stage (characterized by silica-bearing vesicles in the final products) of a two-step vesiculation process.

\section{Acknowledgements}

We thank F. Holtz and B. Scaillet for assistance with the preparation of samples and standard glasses and in FTIR analysis, and F. Holtz for analysis of the standard glasses by Karl-Fisher titration at Hannover University. O. Rouer helped for microprobe analysis, A. Genty (ESEM, Université d'Orléans) for SEM studies, and P. Auger (BRGM Orléans) for clast density measurements. This study was supported by PNRN (CNRS-INSU). This is INSU Contribution number136.

\section{References}

Anderson et al., 1989

A.T Anderson, S Newman, S.N Williams, T.H Druitt, C Skirius, E Stolper $\mathrm{H}_{2} \mathrm{O}, \mathrm{CO}_{2}, \mathrm{Cl}$, and gas in plinian and ash-flow Bishop rhyolite Geology, 17 (1989), pp. 221-225 
Behrens et al., 1996

H Behrens, C Romano, M Nowak, F Holtz, D.B Dingwell

Near-infrared spectroscopic determination of water species in glasses of the system $\mathrm{MAlSi}_{3} \mathrm{O}_{8}(\mathrm{M}=\mathrm{Li}, \mathrm{Na}, \mathrm{K})$ : an interlaboratory study

Chem. Geol., 128 (1996), pp. 41-63

Boudon et al., 1994

G Boudon, J.-L Bourdier, H Traineau

High-energy pyroclastic flows in the recent activity of Mt. Pelée, Martinique.

IAVCEI congress, Ankara

Abst. Vol. (1994)

Bourdier et al., 1989

J.-L Bourdier, G Boudon, A Gourgaud

Stratigraphy of the 1902 and 1929 nuée-ardente deposits, Mt Pelée, Martinique J. Volcanol. Geotherm. Res., 38 (1-2) (1989), pp. 77-96

Burnham, 1979

C.W Burnham

The importance of volatiles constituents

H.S Yoder (Ed.), The Evolution of Igneous Rocks, Princeton Univ. Press, Princeton (1979), pp. 439-482

Bursik, 1993

M.I Bursik

Subplinian eruption mechanisms inferred from volatile and clast dispersal data J. Volcanol. Geotherm. Res., 57 (1993), pp. 57-70

Cashman, 1992

K.V Cashman

Groundmass crystallization of Mount St. Helens dacite 1980-1986: a tool for interpreting shallow magmatic processes

Contrib. Mineral. Petrol., 109 (1992), pp. 431-449

Devine et al., 1995

J.D Devine, J.E Gardner, H.P Brack, G.D Layne, M.J Rutherford

Comparison of microanalytical methods for estimating $\mathrm{H}_{2} \mathrm{O}$ contents of silicic volcanic glasses

Am. Mineral., 80 (1995), pp. 319-328

Dunbar and Kyle, 1992

N.W Dunbar, P.R Kyle

Volatile contents of obsidian clasts in tephra from the Taupo volcanic zone, New Zealand: implications to eruptive processes

J. Volcanol. Geotherm. Res., 49 (1992), pp. 127-145 
Eichelberger and Westrich, 1981

J.C Eichelberger, H.R Westrich

Magmatic volatiles in explosive rhyolitic eruptions

Geophys. Res. Lett., 8 (1981), pp. 757-760

Eichelberger et al., 1986

J.C Eichelberger, C.R Carrigan, H.R Westrich, R.H Price

Non-explosive silicic volcanism

Nature, 323 (1986), pp. 598-602

Fink, 1983

J.H Fink

Structure and emplacement of a rhyolitic obsidian flow: Little Glass Mountain, Medicine Lake Highland, northern California

Geol. Soc. Am. Bull., 94 (1983), pp. 362-380

Fink et al., 1992

J.H Fink, S.W Anderson, C.R Manley

Textural constraints on effusive silicic volcanism: beyond the permeable foam model

J. Geophys. Res., 97 (B6) (1992), pp. 9073-9083

Gardner et al., 1996

J.E Gardner, R.M.E Thomas, C Jaupart, S Tait

Fragmentation of magma during plinian volcanic eruptions

Bull. Volcanol., 58 (1996), pp. 144-162

Gourgaud, 1985

Gourgaud, A., 1985. Mélanges de magmas dans les séries alcalines et calco-alcalines: leur rôle dans la genèse des laves intermédiaires et leur influence sur les mécanismes éruptifs. Exemples pris dans le Massif Central français (Mont-Dore, Chaîne des Puys), à la Martinique (Montagne Pelée, fissure Burgos-Diamant) et au Mexique (Pico de Orizaba). Annales scientifiques de l'Univ. de Clermont-Ferrand II, n86, $522 \mathrm{pp}$.

Haar et al., 1984

L Haar, J.S Gallagher, G.S Kell

NBS/NRC Steam Tables. Thermodynamic and Transport Properties and Computer Programs for Vapor and Liquid States of Water In SI unitsMcGraw Hill, New York (1984)

Hervig et al., 1989

R.L Hervig, N Dunbar, H.R Westrich, P.R Kyle

Pre-eruptive water content of rhyolitic magmas as determined by ion microprobe analyses of melt inclusions in phenocrysts

J. Volcanol. Geotherm. Res., 36 (1989), pp. 293-302 
Hoblitt and Harmon, 1993

R.P Hoblitt, R.S Harmon

Bimodal density distribution of cryptodome dacite from the 1980 eruption of

Mount St. Helens, Washington

Bull. Volcanol., 55 (1993), pp. 421-437

Houghton and Wilson, 1989

B.F Houghton, C.J.N Wilson

A vesicularity index for pyroclastic deposits

Bull. Volcanol., 51 (1989), pp. 451-462

Jaupart and Allègre, 1991

C Jaupart, C.J Allègre

Gas content, eruption rate and instabilities of eruption regime in silicic volcanoes

Earth Planet. Sci. Lett., 102 (1991), pp. 413-429

Jaupart and Tait, 1990

C Jaupart, S Tait

Dynamics of eruptive phenomena

,in: J Nicholls, J.K Russell (Eds.), Reviews in Mineralogy, Modern Methods of Igneous Petrology: Understanding Magmatic Processes, Mineral. Soc. Am. Rev., 24 (1990), pp. 213-238 Series ed. P.H. Ribbe.

Johnson et al., 1994

M.C Johnson, A.T Anderson, M.J Rutherford

Pre-eruptive volatile contents of magmas

,in: M.R Carroll, J.R Holloway (Eds.), Reviews in Mineralogy. Volatiles in

Magmas, Mineral. Soc. Am. Rev., 30 (1994), pp. 281-330

Klug and Cashman, 1994

C Klug, K.V Cashman

Vesiculation of May 18, 1980, Mount St. Helens magma

Geology, 22 (1994), pp. 468-472

Lacroix, 1904

A Lacroix

La Montagne Pelée et ses éruptionsMasson, Paris (1904) 662 pp

Martel, 1996

Martel, C., 1996. Conditions pré-éruptive et dégazage des magmas andésitique de la Montagne Pelée (Martinique): étude pétrologique et expérimentale. PhD. thesis, Univ. Orléans, France: 250 p. 
Magma storage conditions and control of eruption regime in silicic volcanoes: experimental evidence from Mt. Pelée

Earth Planet. Sci. Lett., 156 (1998), pp. 89-99

Newman et al., 1986

S Newman, E.M Stolper, S Epstein

Measurement of water in rhyolitic glasses: calibration of an infrared spectroscopic technique

Am. Mineral., 71 (1986), pp. 1527-1541

Newman et al., 1988

S Newman, S Epstein, E Stolper

Water carbon dioxide and hydrogen isotopes in glasses from the ca. 1340 AD

eruption of the Mono Craters, California: constraints on degassing phenomena and initial volatile content

J. Volcanol. Geotherm. Res., 35 (1988), pp. 75-96

Perret, 1935

F.A Perret

The Eruption of Mt. Pelée 1929-1932Carnegie Inst, WA (1935) Publ. 458, 126 p.

Pichavant, 1987

M Pichavant

Effects of bond $\mathrm{H}_{2} \mathrm{O}$ or liquidus phase relations in haplogranite systems at $1 \mathrm{~kb}$

Am. Mineral., 72 (1987), pp. 1056-1070

Roobol and Smith, 1976

M.J Roobol, A.L Smith

Mont Pelée, Martinique. A pattern of alternating eruptive style

Geology, 4 (1976), pp. 521-524

Scheidegger et al., 1982

K.F Scheidegger, A.N Federman, A.M Tallman

Compositional heterogeneity of tephras from the 1980 eruptions of Mount St.

Helens

J. Geophys. Res., 87 (1982), pp. 10861-10882

Silver and Stolper, 1989

L.A Silver, E Stolper

Water in albitic glasses

J. Petrol., 30 (1989), pp. 667-709 Part 3

Smith and Roobol, 1990

A.L Smith, M.J Roobol

Mt. Pelée, Martinique, a study of an active island-arc volcano

Geol. Soc. Am. (1990), p. 175

Stolper, 1982

E Stolper

The speciation of water in silicate melts 
Geochim. Cosmochim. Acta, 46 (1982), pp. 2609-2620

।

Tait, 1992

S Tait

Selective preservation of melt inclusions in igneous phenocryst

Am Mineral., 77 (1992), pp. 146-155

Thomas et al., 1994

$\mathrm{N}$ Thomas, C Jaupart, S Vergniolle

On the vesicularity of pumice

J. Geophys. Res., 99 (B8) (1994), pp. 15633-15644

Traineau et al., 1989

H Traineau, D Westercamp, J.M Bardintzeff, J.C Mikovsky

The recent pumice eruptions of Mt. Pelée volcano, Martinique: Part I. Depositional sequences, description of pumiceous deposits

J. Volcanol. Geotherm. Res., 38 (1-2) (1989), pp. 17-33

Villemant and Boudon, 1998

B Villemant, G Boudon

Transition from dome-forming to plinian eruptive styles controlled by $\mathrm{H}_{2} \mathrm{O}$ and $\mathrm{Cl}$ degassing

Nature, 392 (1998), pp. 65-69

Villemant et al., 1996

B Villemant, G Boudon, J.-C Komorowski

U-series disequilibrium in arc magmas induced by water-magma interaction

Earth Planet. Sci. Lett., 140 (1996), pp. 259-267

Westercamp and Traineau, 1983a

Westercamp, D., Traineau, H., 1983. Geological map of Mount Pelée at 1/20 000 scale.

Département de la Martinique, ed. BRGM.

Westercamp and Traineau, 1983b

D Westercamp, $\mathrm{H}$ Traineau

The past 5000 years of volcanic activity at Mt. Pelée, Martinique (F.W.I.):

Implications for assessement of volcanic hazards

J. Volcanol. Geotherm. Res., 17 (1983), pp. 159-185

Westrich, 1987

H.R Westrich

Determination of water in volcanic glasses by Karl Fischer titration

Chem. Geol., 63 (1987), pp. 335-340

Westrich and Eichelberger, 1994

H.R Westrich, J.C Eichelberger

Gas transport and bubble collapse in rhyolitic magma: an experimental approach

Bull. Volcanol., 56 (1994), pp. 447-458 